Provided for non-commercial research and educational use only. Not for reproduction or distribution or commercial use.

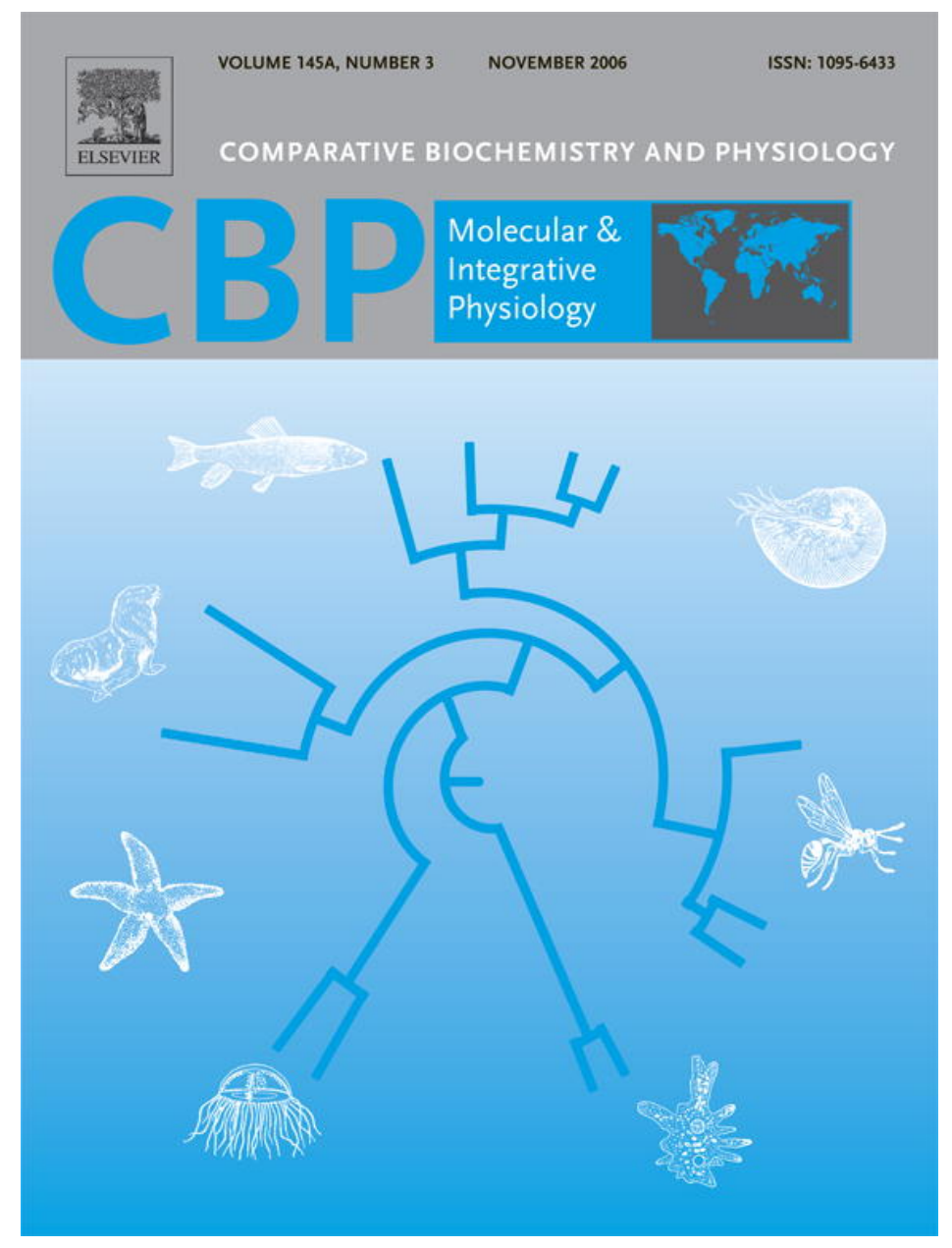

This article was originally published in a journal published by Elsevier, and the attached copy is provided by Elsevier for the author's benefit and for the benefit of the author's institution, for non-commercial research and educational use including without limitation use in instruction at your institution, sending it to specific colleagues that you know, and providing a copy to your institution's administrator.

All other uses, reproduction and distribution, including without limitation commercial reprints, selling or licensing copies or access,

or posting on open internet sites, your personal or institution's website or repository, are prohibited. For exceptions, permission may be sought for such use through Elsevier's permissions site at: 


\title{
Microassays for a set of enzymes in individual small marine copepods
}

\author{
Susanna Knotz*, Maarten Boersma, Reinhard Saborowski \\ Biologische Anstalt Helgoland, Foundation Alfred Wegener Institute for Polar and Marine Research, P. O. Box 180, D-27483 Helgoland, Germany
}

Received 8 February 2006; received in revised form 20 July 2006; accepted 26 July 2006

Available online 4 August 2006

\begin{abstract}
Fluorogenic assays for a set of five hydrolytic enzymes involved in digestion and food utilization (alanine and arginine aminopeptidase, lipase/ esterase, chitobiase, and beta-glucosidase) were optimized to measure activities of these enzymes in the same extracts of individual small North Sea copepods. The enzyme activities of Acartia clausi, Centropages typicus, Corycaeus anglicus, Paracalanus parvus, and Temora longicornis showed distinct species specific activity patterns, but also high intra-specific variability. Protein, lipids, carbon and nitrogen (C, N) were determined with micro-scale assays in individual copepods or in batches of 10 to 50 animals. Water soluble protein contents ranged from $16 \%$ to $38 \%$, and lipid contents from $2.4 \%$ to $5.5 \%$ of dry mass. The molar $\mathrm{C} / \mathrm{N}$ ratios were between 4.1 and 4.5 . The presented microassays provide suitable tools for studying physiological reactions of copepods and other small pelagic crustaceans in response to variable environmental conditions.
\end{abstract}

(C) 2006 Elsevier Inc. All rights reserved.

Keywords: North Sea copepods; Digestive enzymes; Fluorogenic substrates; Lipid; Protein; C/N ratio

\section{Introduction}

Copepods hold key positions in pelagic food webs and contribute significantly to the transfer of matter and energy between trophic levels. However, the detailed functions of particular species or developmental stages within pelagic food webs are still largely unknown due to the variety of possible trophic interactions.

The biochemical utilization of food is facilitated by a set of digestive enzymes that are synthesized in the midgut region of copepods (Arnaud et al., 1980; Brunet et al., 1994). The activities of such enzymes reflect the potential to digest different organic matter and may indicate adaptations to different food sources (Rodriguez et al., 1994; Jones et al., 1997; Le Vay et al., 2001). Even though digestive enzymes have been measured extensively in copepods since the 1970s (Boucher and Samain, 1974; Mayzaud and Conover, 1976; Mayzaud and Poulet, 1978), the sensitivity of the enzyme assays was low, and hence mostly applicable to pooled samples of up to several hundred copepods or to larger animals (Johnston and Freeman, 2005). Accordingly, information on developmental stages or species was difficult to

\footnotetext{
* Corresponding author. Tel.: +49 4725819 326; fax: +49 4725819369.

E-mail address: sknotz@awi-bremerhaven.de (S. Knotz).
}

obtain, while information on individual copepods was not available. However, this information is crucial in interpreting physiological conditions and trophic interactions.

In this study, we adapted sensitive enzyme assays previously used to detect enzymatic activity in water samples (Hoppe, 1983; Oosterhuis et al., 2000; Sastri and Roff, 2000) to measure enzyme activities in individual copepods. The catalytic potential in different species may provide additional information on the utilization of food that is preferably eaten by these animals or help to explain the dynamics of nutrient uptake. Beyond that, we analysed general nutritive parameters such as lipid and water soluble protein content of the animals as well as their $\mathrm{C}$ and $\mathrm{N}$ content. As test organisms, we used the most abundant pelagic North Sea copepods around Helgoland known for their carnivorous, omnivorous and more herbivorous feeding modes (Kleppel, 1993). In this study we concentrated on copepods to establish the analytical methods. However, the analytical procedure will be suitable for a wide range of small pelagic crustacean or their developmental stages.

\section{Materials and methods}

The copepods, Acartia clausi, Centropagus typicus, Corycaeus anglicus, Paracalanus parvus and Temora longicornis 
Table 1

List of studied species: abbreviations, feeding preferences, distribution (Turner, 1984; Kouwenberg, 1993; Krause, 1995; Mauchline, 1998)

\begin{tabular}{|c|c|c|c|}
\hline Species & Abbreviations & Feeding mode & Distribution \\
\hline Corycaeus anglicus & $\mathrm{Ca}$ & Carnivorous & $\begin{array}{l}\text { Neritic, warm to } \\
\text { cold temperate, } \\
\text { Atlantic and Pacific }\end{array}$ \\
\hline Acartia clausi & $A c$ & Omnivorous & $\begin{array}{l}\text { Oceanic to neritic, } \\
\text { warm to cold temperate, } \\
\text { Atlantic and Pacific }\end{array}$ \\
\hline Centropages typicus & $C t$ & Omnivorous & $\begin{array}{l}\text { Oceanic, marine, warm } \\
\text { to cold temperate, } \\
\text { Atlantic }\end{array}$ \\
\hline Temora longicornis & $T l$ & Omnivorous & $\begin{array}{l}\text { Neritic, marine to } \\
\text { estuarine, warm to cold } \\
\text { temperate, Atlantic, }\end{array}$ \\
\hline Paracalanus parvus & $P p$ & $\begin{array}{l}\text { Most } \\
\text { herbivorous }\end{array}$ & $\begin{array}{l}\text { Oceanic to neritic, } \\
\text { worldwide, warm to } \\
\text { cold temperate, Atlantic }\end{array}$ \\
\hline
\end{tabular}

(Table 1) were sampled in autumn 2003 off Helgoland $\left(54^{\circ} 11 \mathrm{~N}\right.$, $7^{\circ} 54 \mathrm{E}$, North Sea, German Bight). Females were selected, transferred to aquaria $\left(1 \mathrm{~L}, 15 \pm 1{ }^{\circ} \mathrm{C}\right)$ and fed with a mixture of flagellates Rhodomonas sp., Isochrysis sp. and Oxyrrhis marina (Klein-Breteler, 1980). The aim of standardising the feeding condition of all copepods was to measure species peculiarities rather than effects due to nutritional differences. After 2 days of feeding females were selected, shortly rinsed with deionised water, blotted dry and frozen at $-80{ }^{\circ} \mathrm{C}$.

Cephalothorax lengths and widths were measured in 20-30 live individuals under a dissection microscope using a video analysis system (analysis, Soft Imaging System).

Water soluble protein content of individual females was measured with the bicinchoninic acid assay (BCA, Pierce Ltd.) (Smith et al., 1985). The method was adapted for the use in 96well microplates. Individuals were ground in reaction cups with a micropestle in $55 \mu \mathrm{L}$ deionised water, while being cooled on ice. The extracts were centrifuged for $10 \mathrm{~min}\left(15,000 \times \mathrm{g}, 4^{\circ} \mathrm{C}\right)$. Fifty $\mu \mathrm{L}$ of supernatant were mixed with $250 \mu \mathrm{L}$ test kit reagents and incubated for $1 \mathrm{~h}$ at room temperature. The microplates were read at $550 \mathrm{~nm}$ (Dynatech MR 7000). Bovine serum albumin (BSA, 1 to $5 \mu \mathrm{g}$ per well) was used as standard.

Total lipids were measured with the sulphophosphovanillin method (Zöllner and Kirsch, 1962). A commercial test kit (Merckotest 3321) was adjusted for the use in 96-well microplates. Copepods (10 to 35 individuals per replicate) were boiled for $10 \mathrm{~min}$ in $60 \mu \mathrm{L}$ concentrated sulphuric acid in stoppered glass vials. After cooling to room temperature, $30 \mu \mathrm{L}$ of the solution was transferred into microplate wells. Samples received $300 \mu \mathrm{L}$ of phosphovanillin reagent $\left(8 \mathrm{mmol} \mathrm{L}^{-1}\right)$ and blanks were prepared with $300 \mu \mathrm{L}$ of phosphoric acid $(11.9 \mathrm{~mol}$ $\left.\mathrm{L}^{-1}\right)$. Standards (1.2 to $6 \mu \mathrm{g}$ serum lipids/well) were treated alike. A gravimetric control of copepod lipids could not be done due to the extreme low amount of material. The optical density (OD) was read at $530 \mathrm{~nm}$. A lipid extraction step was not necessary as preliminary experiments showed that the yield did not improve after extraction with chloroform/methanol.

Carbon, nitrogen and dry mass $(\mathrm{dm})$ were analysed in pools of 25 to 50 freeze dried females with a CHN analyser (Fisions
Instruments EA 1108). Acetanilide (Thermo Quest, 338 36700) served as standard.

Enzyme activities were measured in individual females. These were homogenized with a micropestle in $200 \mu 1$ of ice cold Tris/ $\mathrm{HCl}$ buffer $\left(0.1 \mathrm{~mol} \mathrm{~L}^{-1}, \mathrm{pH} 8\right)$ and centrifuged for $10 \mathrm{~min}$ at $15,000 \times \mathrm{g}$ and $4{ }^{\circ} \mathrm{C}$. Extracts of a single animal were used for the analysis of two protein degrading exopeptidases (arginine and alanine aminopeptidase), lipid hydrolyzing esterase/lipase, and two carbohydrases (chitobiase and beta-glucosidase). Assays were run at $25^{\circ} \mathrm{C}$ with 5 to $40 \mu \mathrm{L}$ of sample. Stock solutions of the substrates (Table 2) were prepared in ethylene glycol monomethylether $\left(5 \mathrm{mmol} \mathrm{L}^{-1}\right)$. Substrate concentrations in the assays were $100 \mu \mathrm{mol} \mathrm{L}{ }^{-1}$ in a total volume of $500 \mu \mathrm{L} \mathrm{Tris/HCl}$ (0.1 mol L $\left.{ }^{-1}\right)$ or citrate-phosphate buffer (McIlvaine, 1921). Fluorescence was measured at $360 \mathrm{~nm}$ (excitation) and $450 \mathrm{~nm}$ (emission) for 10 to $60 \mathrm{~min}$ with a Kontron SFM 25 device. Blanks were run in parallel. The rate of autolysis was tested for each substrate at all given assay conditions and subtracted from the assay-results. Standard curves were prepared with 4-betamethylubelliferone (MUF) and 7-amino-4-methylcoumarin (AMC). The effect of $\mathrm{pH}$ on MUF and AMC fluorescence was determined. Enzyme activities were calculated in relation to the average water soluble protein content of either species and were presented as specific activities (nmol h${ }^{-1} \mathrm{mg}_{\text {prot }}^{-1}$ ). The linearity of the assay was tested with extracts of $A$. clausi and T. longicornis. The fluorescence increased linearly between $2 \%$ and $8 \%$ of copepod extract in the final assay preparation $(y=0.79 * x+$ $\left.0.0001, r^{2}=0.98, p=0.01\right)$. The $\mathrm{pH}$-profiles of all enzymes were determined between $\mathrm{pH} 4$ and $\mathrm{pH} 8$ with extracts of $T$. longicornis females. Lipase/esterase and peptidase showed maximum activities at $\mathrm{pH} 7$ and carbohydrases at $\mathrm{pH}$ 5. The standard assays for these enzymes were run at the respective $\mathrm{pH}$ of maximum activity (Table 2).

\section{Results and discussion}

The copepod species selected for our study overlap widely in their area of distribution and are abundant in the North Sea. However, they differ distinctly in feeding habits and in size. The smaller species A. clausi, C. anglicus and P. parvus weighed 4.6 to $6.6 \mu \mathrm{g}$ (dry mass) while the dry mass of T. longicornis

Table 2

List of enzymes, substrates, and assay conditions

\begin{tabular}{|c|c|c|c|c|}
\hline Enzyme & Substrate & Source & $\begin{array}{l}\text { Buffer } \\
\text { system }\end{array}$ & $\mathrm{pH}$ \\
\hline Chitobiase & $\begin{array}{l}\text { 4-Methylumbelliferyl } \\
\mathrm{N} \text {-acetyl-beta-D-glucosaminide }\end{array}$ & $\begin{array}{l}\text { Sigma } \\
2133\end{array}$ & McIlvaine & 5 \\
\hline $\begin{array}{l}\text { Beta- } \\
\text { glucosidase }\end{array}$ & $\begin{array}{l}\text { 4-Methylumbelliferyl } \\
\text { beta-D-glucoside }\end{array}$ & $\begin{array}{l}\text { Sigma } \\
3633\end{array}$ & McIlvaine & 5 \\
\hline Esterase/lipase & 4-Methylumbelliferyl butyrate & $\begin{array}{l}\text { Fluka } \\
19362\end{array}$ & Tris/HCl & 7 \\
\hline $\begin{array}{l}\text { Alanine } \\
\text { aminopeptidase }\end{array}$ & $\begin{array}{l}\text { L-Alanine-4-methyl-7- } \\
\text { coumarinylamide- } \\
\text { trifluoroacetate }\end{array}$ & $\begin{array}{l}\text { Fluka } \\
05198\end{array}$ & Tris/HCl & 7 \\
\hline $\begin{array}{l}\text { Arginine } \\
\text { aminopeptidase }\end{array}$ & $\begin{array}{l}\text { L-Arginine-7-amido- } \\
\text { 4-methylcoumarin hydrochloride }\end{array}$ & $\begin{array}{l}\text { Sigma } \\
2027\end{array}$ & Tris/HCl & 7 \\
\hline
\end{tabular}


Table 3

Morphometric and nutritive data (mean \pm S.D.); $\mathrm{Cs}=$ cephalosome; $\mathrm{dm}=$ dry mass; protein= water soluble protein

\begin{tabular}{|c|c|c|c|c|c|c|c|c|}
\hline Species & $\begin{array}{l}\text { Dry mass* } \\
\left(\mu \mathrm{g} \text { ind }^{-1}\right)\end{array}$ & $\begin{array}{l}\text { Cs length } \\
\left(\mu \mathrm{m} \text { ind }^{-1}\right)\end{array}$ & $\begin{array}{l}\text { Cs width } \\
\left(\mu \mathrm{m} \text { ind }^{-1}\right)\end{array}$ & $\begin{array}{l}\text { Carbon* } \\
(\% \mathrm{dm})\end{array}$ & $\begin{array}{l}\text { Nitrogen* } \\
(\% \mathrm{dm})\end{array}$ & Molar C:N* & $\begin{array}{l}\text { Lipid** } \\
(\% \mathrm{dm})\end{array}$ & $\begin{array}{l}\text { Protein } \\
(\% \mathrm{dm})\end{array}$ \\
\hline $\mathrm{Ca}$ & $4.62 \pm 0.04(n=3)$ & $636 \pm 33(n=20)$ & $272 \pm 11(n=20)$ & $39.8 \pm 1.0(n=3)$ & $10.6 \pm 0.3(n=3)$ & $4.36 \pm 0.01 \quad(n=3)$ & $3.9 \pm 0.8(n=5)$ & $38 \pm 9(n=20)$ \\
\hline$A c$ & $6.02 \pm 0.37(n=4)$ & $772 \pm 31(n=92)$ & $250 \pm 10(n=92)$ & $44.0 \pm 0.3(n=4)$ & $12.3 \pm 0.3(n=4)$ & $4.19 \pm 0.07(n=4)$ & $5.5 \pm 1.0(n=21)$ & $24 \pm 8(n=24)$ \\
\hline$C t$ & $37.86 \pm 1.57(n=4)$ & $1208 \pm 55(n=33)$ & $504 \pm 20(n=33)$ & $43.9 \pm 0.7(n=4)$ & $12.5 \pm 0.2(n=4)$ & $4.10 \pm 0.03(n=4)$ & $2.4 \pm 0.4(n=4)$ & $19 \pm 5(n=24)$ \\
\hline$T l$ & $30.35 \pm 4.79(n=3)$ & $824 \pm 92(n=20)$ & $491 \pm 40(n=20)$ & $45.0 \pm 0.3(n=3)$ & $12.1 \pm 0.1(n=3)$ & $4.33 \pm 0.01 \quad(n=3)$ & $4.5 \pm 0.2(n=4)$ & $16 \pm 4(n=30)$ \\
\hline$P p$ & $6.62 \pm 0.26(n=2)$ & n.d. & n.d. & $44.4 \pm 1.3(n=2)$ & $11.5 \pm 0.4(n=2)$ & $4.50 \pm 0.29(n=2)$ & $5.0 \pm 1.2(n=4)$ & $16 \pm 8(n=24)$ \\
\hline
\end{tabular}

* 25 to 50 individuals per replicate; $* * 10$ to 35 individuals per replicate

and C. typicus amounted to 30-38 $\mu \mathrm{g}$ (Table 3). Due to the small size of copepods the measurements of enzyme activities and storage products require optimised methods such as microscale extraction procedures, sensitive substrates, and optimum assay conditions.

Enzyme activities were highest at neutral to slightly acidic conditions: the exopeptidases and esterase/lipase at $\mathrm{pH} 7$ and
8 (Fig. 1a, b, c), and the carbohydrases at pH 5 and 6 (Fig. 1d, e). These activity optima correspond with the neutral to slightly acidic $\mathrm{pH}$ that was determined in vivo in the gut of Calanus helgolandicus (Pond et al., 1995). The fluorescence of AMC remained constant between $\mathrm{pH} 4$ and 8 while the fluorescence of MUF increased exponentially above $\mathrm{pH} 7$ (Fig. 2). Accordingly, activities measured with MUF substrates at higher $\mathrm{pH}$ appear
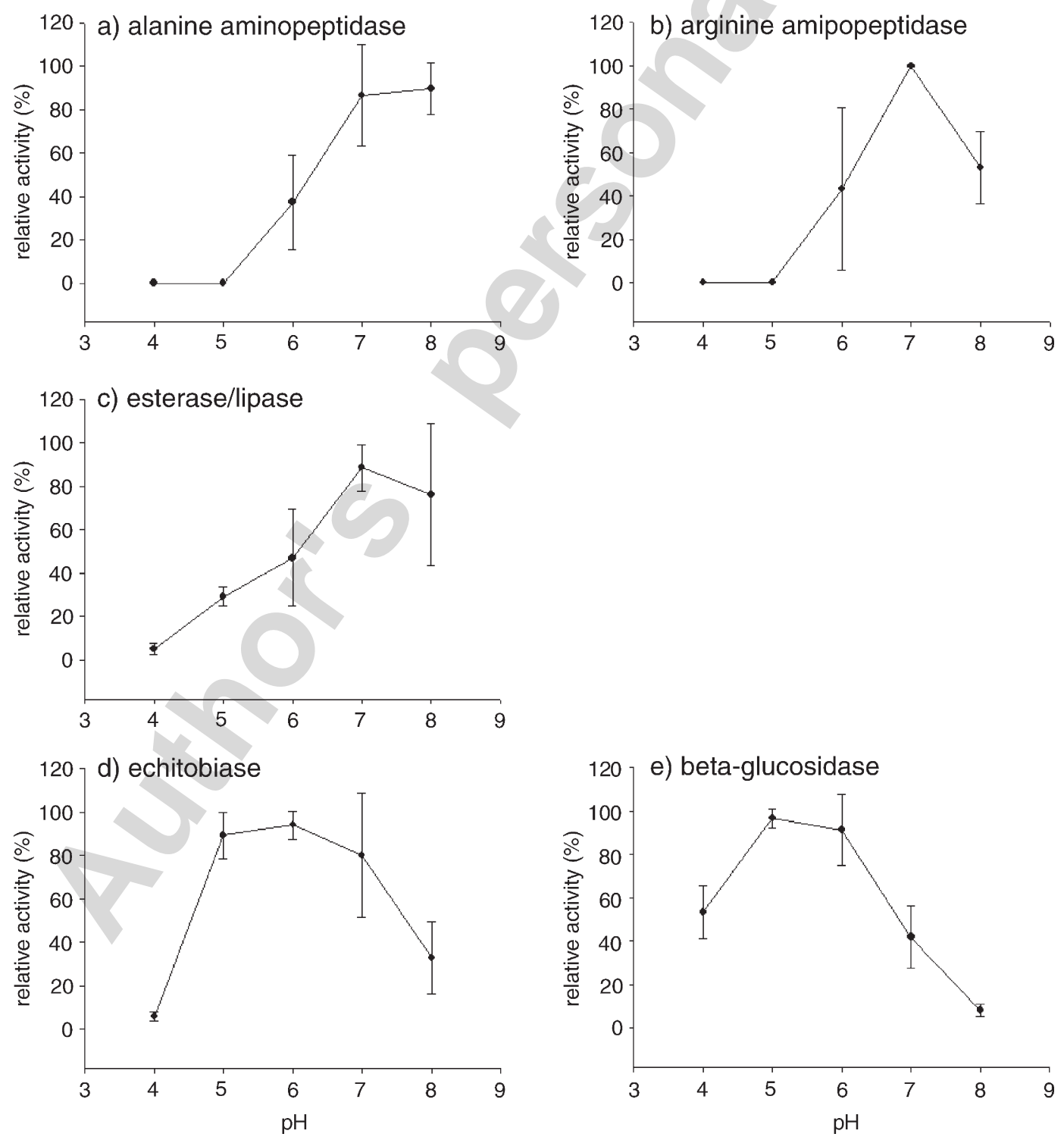

Fig. 1. pH-profiles of all enzymes measured with extracts of T. longicornis females $(n=3$; means \pm S.D. $)$. 
a) $A M C$

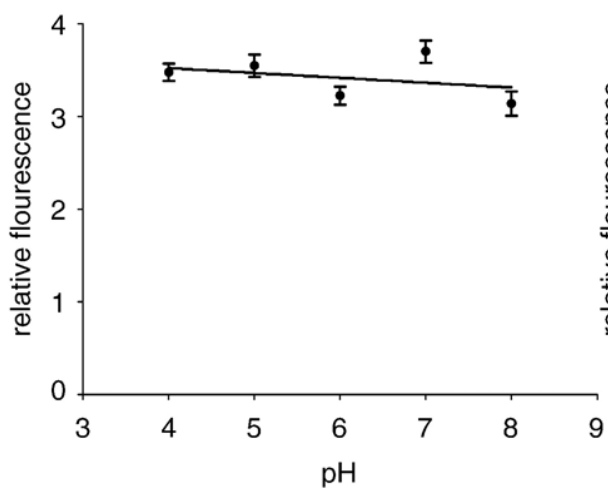

b.) MUF

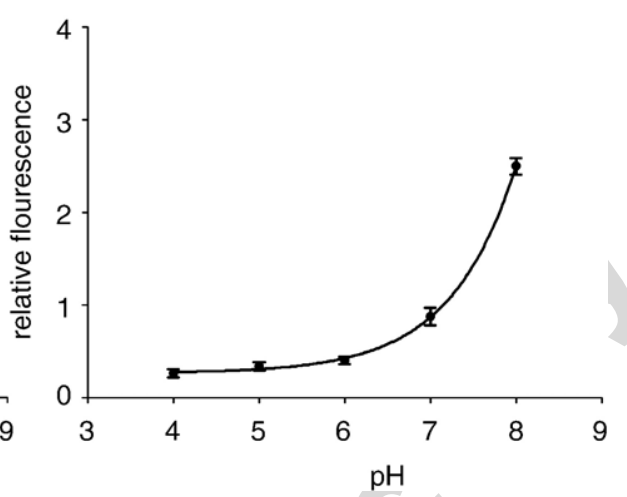

Fig. 2. Effects of pH on the fluorescence of (a) 7-amino-4-methylcoumarin (AMC); linear regression and (b) 4-beta-methylumbelliferone (MUF); exponential regression $(n=4$; means \pm S.D. $)$.

higher than they are. This effect must be compensated for by applying appropriate standards.

In all species activities of arginine aminopeptidase were higher than activities of alanine aminopeptidase (Fig. 3a, b). Both activities were closely correlated $\left(r^{2}=0.64, n=34, p<0.00001\right)$ which may indicate overlapping substrate specificity or co-expression of both enzymes. Since phytoplankton contains less protein than zooplankton, herbivores have to increase their catalytic ability to cover their nitrogen demand from proteins. Apparently, aminopeptidase activities increased with the degree of herbivory. T. longicornis and $P$. parvus are considered more herbivorous than C. typicus and A. clausi, while C. anglicus is a carnivore (Turner, 1984; Kouwenberg, 1993; Mauchline, 1998). C. anglicus showed the lowest and P. parvus and C. typicus the
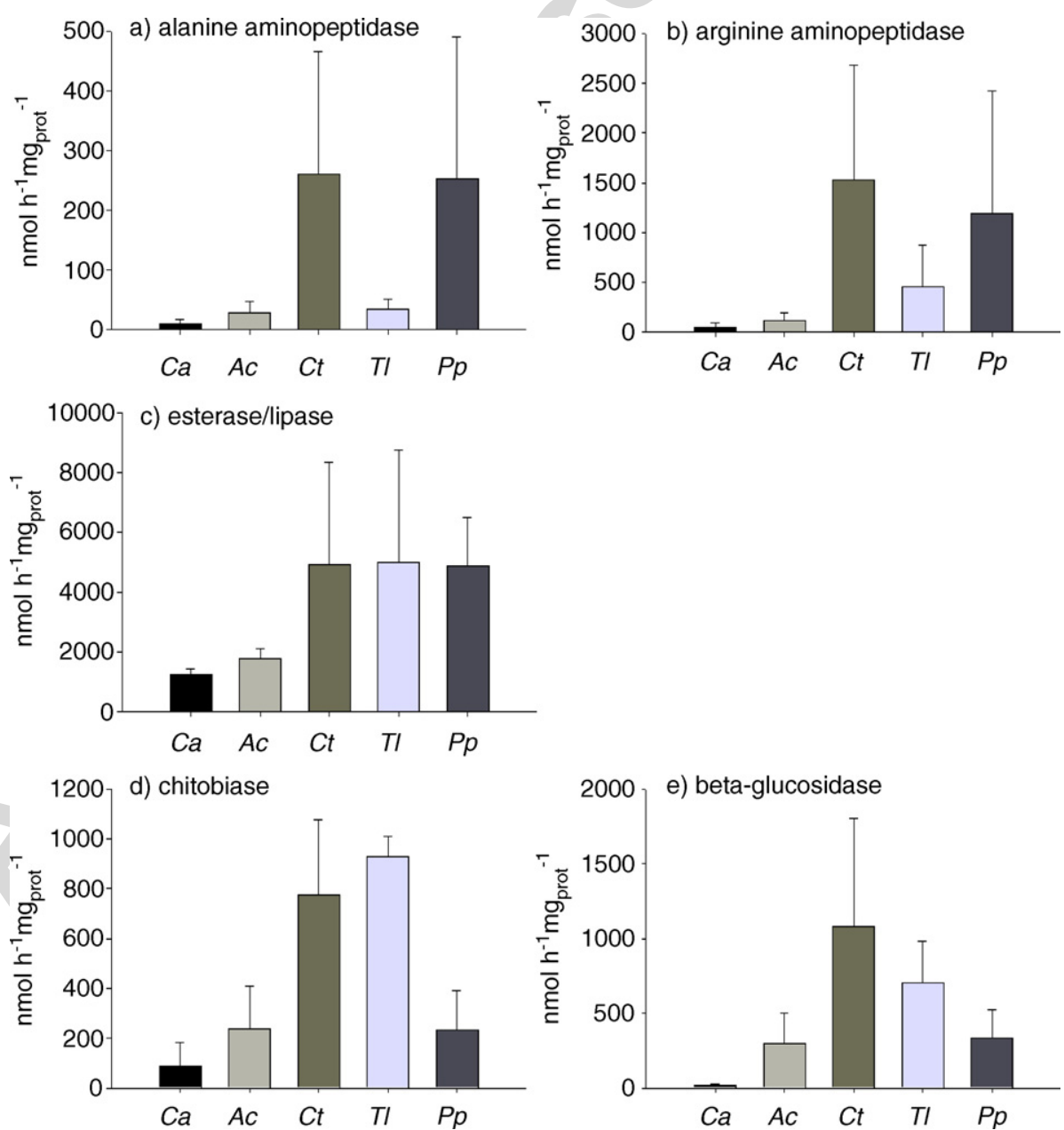

Fig. 3. Specific activities of enzymes ( $n=4-6$; means \pm S.D.). For abbreviations refer to Table 1. 
highest amino-peptidase activities. Therefore, the exopeptidases analysed here seem as suitable for the interpretation of zooplankton feeding modes as shown previously for endopeptidases such as trypsin (Rodriguez et al., 1994; Jones et al., 1997; Le Vay et al., 2001).

MUF-butyrate, was hydrolyzed at rates of $1200 \mathrm{nmol} \mathrm{h}^{-1}$ $\mathrm{mg}_{\text {prot }}^{-1}$ in C. anglicus to $5000 \mathrm{nmol} \mathrm{h}^{-1} \mathrm{mg}_{\text {prot }}^{-1}$ in T. longicornis (Fig. 3c). These particularly high activities of esterase/lipase clearly reflect the high potential of all species to utilize lipids. None of the species from the North Sea studied here store significant amounts of lipids (Table 3). Therefore, these species highly depend on the immediate and rapid utilization of alimentary lipids, and thus, on high esterase/lipase activities. Besides their nutritive value, lipids are important compounds of egg yolk and thus crucial for reproductive success. All copepods used in this study were adult females that were able to reproduce. Accordingly, high esterase/lipase activities may fuel vitellogenesis in reproducing females by utilizing alimentary lipids (Gatten et al., 1980).

Crustaceans express two forms of chitinolytic enzymes that are involved in moulting or digestion (Peters et al., 1999). Since adult copepods do not moult, they most likely express exclusively digestive chitobiase. It hydrolyzes oligomeres of $\mathrm{N}$ acetyl-glucosamines (NAG) derived from chitin degradation to NAG monomers. Total activities of chitobiase ranged between 90 and $930 \mathrm{nmol} \mathrm{h}^{-1} \mathrm{mg}_{\text {prot. }}^{-1}$ Surprisingly, species considered more carnivorous showed low chitobiase activities, while the more herbivorous species expressed elevated activities. Therefore, herbivorous copepods may be capable of utilising diatom chitin by elevated chitobiase activities as suggested for Antarctic krill (Saborowski and Buchholz, 1999).

Beta-glucosidase hydrolyzes terminal beta-D-glucose from various polysaccharide sources such as cellulose or laminarin and is involved in many metabolic processes. Accordingly, betaglucosidase should exhibit high activities in all studied species. However, we found a wide range of activities from as low as $15 \mathrm{nmol} \mathrm{h}^{-1} \mathrm{mg}_{\text {prot }}^{-1}$ in C. anglicus to $1100 \mathrm{nmol} \mathrm{h}^{-1} \mathrm{mg}_{\text {prot }}^{-1}$ in $C$. typicus. Therefore, we have to consider that additional enzymes with wide specificities may complement beta-glucosidase activity, e.g. galactosidases or alpha-glucosidases.

The sensitivity of the lipid assay was not high enough to analyse individual copepods, but required batches of 15 to 40 specimens. Crude extracts measured with serum lipid standards provided with the test kit probably overestimate total lipid values (Barnes and Blackstock, 1973; Båmstedt, 1975). However, Alonzo et al. (2000) showed that the amount of total lipids measured by the sulphosphovanillin reaction closely correlated with the fluorescence based measurement of neutral and polar lipids in Paraeuchaeta antarctica. Our analysis showed very low lipid values in all species ranging from $2.4 \%$ to $5.5 \%$ of dry mass (Table 3). Polar species, in contrast, may accumulate as much as $73 \%$ lipids (Båmstedt, 1986). Apparently, none of the analysed copepods were capable of storing significant amounts of lipids, which was confirmed by low $\mathrm{C} / \mathrm{N}$-ratios (Table 3 ). These species are not exposed to extended periods of food limitation. They seem to be adapted to rapid utilization of alimentary lipids facilitated by high esterase/lipase activities.
In contrast to their lipid contents, all species were rich in protein, but showed considerable inter-specific variation. Water soluble protein contents ranged from $16 \%$ in P. parvus and $T$. longicornis up to $38 \%$ of dry mass in C. anglicus (Table 3 ). Total protein concentrations of $60 \%$ of dry mass were measured in $T$. longicornis in spring and summer in Norway (Evjemo et al., 2003 ), while $20 \%$ protein of dry mass were measured in cultured T. longicornis (Oosterhuis and Baars, 1985). Individual differences in nutritional history may cause such intra-specific variations (Båmstedt, 1988).

There is strong evidence that proteolytic activity in crustacean larvae decreases when carnivorous feeding increases during ontogeny (Le Vay et al., 2001). In contrast, herbivorous fish species showed highest ratios of amylase to protease activity, while the most carnivorous species had high proteolytic activities (Hidalgo et al., 1999). Johnston and Freeman (2005) showed that different species of crabs express complex suits of digestive enzymes and that the relative activities of enzymes indicate different speciesspecific dietary niches. Accordingly, it is important to evaluate a set of enzymes to better interpret physiological characteristics and to distinguish them from nutritional effects.

In conclusion, this work is an important step forward in understanding the physiological reactions and ecological functions of copepods within a complex and ever changing environment as it enables us to analyse important biochemical parameters in individual animals. The range of fluorogenic substrates can be extended to identify further important enzymes in the copepods' digestive physiology. The next step now is to investigate, whether the patterns found here are inherent properties of the species, or are dependent on the feeding conditions at the time. If copepods do change their enzymatic tools throughout a season, we might be able to use enzyme activities to infer the feeding modes of the animals in situ.

\section{Acknowledgements}

We thank Karin Bickmeyer, Gerrit Sahling, Kathrin Schachmann and Melanie Sapp for laboratory support and the crew of $\mathrm{R} / \mathrm{V}$ Aade for sampling plankton. This study was carried out within the "Helgoland Food Web Project", and funded as a part of the GLOBEC-Germany program by the German Federal Ministry of Education and Research (BMBF).

\section{References}

Alonzo, F., Mayzaud, P., Razoul, S., 2000. Egg production, population structure and biochemical composition of the subantarctic copepod Paraeuchaeta antarctica in the Kerguelen Archipelago. Mar. Ecol., Prog. Ser. 205, 207-217.

Arnaud, J., Brunet, M., Mazza, J., 1980. Comparative structure and ultrastructure of the midgut in several species of calanoid copepods. Zoomorphologie 95, 213-233.

Båmstedt, U., 1975. Studies on the deep-water pelagic community of Korsfjorden, Western Norway - ecological aspects of individual variations in weight and protein and lipid content of Euchaeta norvegica. Sarsia 59, 31-46.

Båmstedt, U., 1986. Chemical composition and energy content. In: Corner, E.D.S., O'Hara, S.C.M. (Eds.), The Biological Chemistry of Marine Copepods. Clarendon Press, Oxford, pp. 1-58.

Båmstedt, U., 1988. Ecological significance of individual variability in copepod bioenergetics. Hydrobiologia 167/168, 43-59. 
Barnes, H., Blackstock, J., 1973. Estimation of lipids in marine animals and tissues: detailed investigation of the sulphophosphovanillin method for total lipids. J. Exp. Biol. Ecol. 12, 103-118.

Boucher, J., Samain, J.F., 1974. L 'activité amylasique indice de la nutrition du zooplancton; mise en evidence d'un rythme quotidien en zone d'upwelling. Tethys 6, 179-188.

Brunet, M., Arnaud, J., Mazza, J., 1994. Gut structure and digestive cellular processes in marine crustacea. Oceanogr. Mar. Biol. Annu. Rev. 32, 335-367.

Evjemo, J.O., Reitan, K.I., Olsen, Y., 2003. Copepods as live food organisms in the larval rearing of halibut larvae (Hippoglossus hippoglossus L.) with special emphasis on the nutritional value. Aquaculture 227, 191-210.

Gatten, R.R., Sargent, J.R., Forsberg, T.E.V., O’Hara, S.C.M., Corner, E.D.S., 1980. On the nutrition and metabolism of zooplankton: XIV. Utilization of lipid by Calanus helgolandicus during maturation and reproduction. J. Mar. Biol. Assoc. U.K. 60, 391-399.

Hidalgo, M.C., Urea, E., Sanz, A., 1999. Comparative study of digestive enzymes in fish with different nutritional habits. Proteolytic and amylase activities. Aquaculture 170, 267-283.

Hoppe, H.G., 1983. Significance of exoenzymatic activities in the ecology of brackish water: measurements by means of methylumbelliferyl-substrates. Mar. Ecol., Progr. Ser. 11, 299-308.

Johnston, D., Freeman, J., 2005. Dietary preference and digestive enzyme activities as indicators of trophic resource utilization by six species of crab. Biol. Bull. Mar. Biol. Lab., Woods Hole. Mass. 208, 36-46.

Jones, D.A., Kumlu, M., Le Vay, L., Fletcher, D.J., 1997. The digestive physiology of herbivorous, omnivorous and carnivorous crustacean larvae: a review. Aquaculture 155, 289-299.

Klein-Breteler, W.C.M., 1980. Continuous breeding of marine pelagic copepods in the presence of heterotrophic dinoflagellates. Mar. Ecol., Prog. Ser. 2, 229-233.

Kleppel, G.S., 1993. On the diets of calanoid copepods. Mar. Ecol., Prog. Ser. 99, 183-195.

Kouwenberg, J.H.M., 1993. Sex ratio of calanoid copepods in relation to population composition in the Northwestern Mediterranean. Crustaceana 64, 281-299.

Krause, M., 1995. A review of hydrographic controls on the distribution of zooplankton biomass and species in the North Sea with particular reference to a survey conducted in January-March 1987. Prog. Oceanogr. 35, 81-152.

Le Vay, L., Jones, D.A., Puello-Cruz, A.C., Sangha, R.S., Ngamphongsai, C., 2001. Digestion in relation to feeding strategies exhibited by crustacean larvae. Comp. Biochem. Physiol., A 128, 621-628.

Mauchline, J., 1998. The biology of calanoid copepods. Adv. Mar. Biol. 33. Academic Press, London.
Mayzaud, P., Conover, R.J., 1976. Influence of potential food supply on the activity of digestive enzymes of neritic zooplankton. Proc. 10th Europ. Symp. on Mar. Biol. Population Dynamics. Vol. 2: Population Dynamics, Universa Press, Ostende, Belgium, pp. 415-427.

Mayzaud, P., Poulet, S.A., 1978. The importance of the time factor in the response of zooplankton to varying concentrations of naturally occurring particulate matter. Limnol. Oceanogr. 23, 1144-1154.

McIlvaine, T.C., 1921. A buffer solution for colorimetric comparison. J. Biol. Chem. 49, 183-186.

Oosterhuis, S.S., Baars, M.A., 1985. On the usefulness of digestive enzyme activity as index for feeding activity in copepods. Hydrobiol. Bull. 19, 89-100.

Oosterhuis, S.S., Baars, M.A., Klein-Breteler, W.C.M., 2000. Release of the enzyme chitobiase by the copepod Temora longicornis: characteristics and potential tool for estimating crustacean biomass production in the sea. Mar. Ecol., Prog. Ser. 196, 195-206.

Peters, G., Saborowski, R., Buchholz, F., Mentlein, R., 1999. Two distinct forms of the chitin-degrading enzyme $N$-acetyl-beta-D-glucosaminidase in the Antarctic krill: specialists in digestion and moult. Mar. Biol. 134, 697-703.

Pond, D.W., Harris, R.P., Brownlee, C., 1995. A microinjection technique using a $\mathrm{pH}$-sensitive dye to determine the gut $\mathrm{pH}$ of Calanus helgolandicus. Mar. Biol. 123, 75-79.

Rodriguez, A., Le Vay, L., Mourente, G., Jones, D.A., 1994. Biochemical composition and digestive enzyme activity in larvae and postlarvae of $\mathrm{Pe}$ naeus japonicus during herbivorous and carnivorous feeding. Mar. Biol. 118, 45-51.

Saborowski, R., Buchholz, F., 1999. A laboratory study on digestive processes in the Antarctic krill, Euphausia superba, with special regard to chitinolytic enzymes. Polar Biol. 21, 295-304.

Sastri, A.R., Roff, J.C., 2000. Rate of chitobiase degradation as a measure of development rate in planktonic crustacea. Can. J. Fish. Aquat. Sci. 57, 1965-1968.

Smith, P.K., Krohn, R.I., Hermanson, G.T., Mallia, A.K., Gartner, F.H., Provenzano, M.D., Fujimoto, E.K., Goeke, N.M., Olson, B.J., Klenk, D.C., 1985. Measurement of protein using bicinchoninic acid. Anal. Biochem. $150,76-85$.

Turner, J.T., 1984. The feeding ecology of some zooplankters that are important prey items of larval fish. NOAA Tech. Rep. NMFS 7, 1-28.

Zöllner, N., Kirsch, K., 1962. Über die quantitative Bestimmung von Lipoiden (Mikromethode) mittels der vielen natürlichen Lipoiden (allen bekannten Plasmalipoide) gemeinsamen Sulfosphovanillin-Reaktion. Z. Ges. Exp. Med. 135, 545-561. 